\title{
The expression and conceptualization of motion through space and manner of motion in Arabic and English: A comparative analysis
}

\author{
Ghadah AlMurshidi
}

\begin{abstract}
This paper is a comparative analysis of English and Arabic expressions of motion events using narratives of Chafe's (1980) Pear Story elicited from native speakers of both languages. The native-speaker English narratives were elicited by Feiz (2007). A discourse analytic approach is used to examine how speakers of Arabic and English indicate motion through path, manner, and ground. The data consist of 45 elicited oral narratives. The narratives are all based on Chafe's (1990) Pear Film, which is a 6minute film with many characters, but no dialogue. Fifteen of these are in Arabic, fifteen in English by Arabic speakers, and fifteen in English by native English speakers. The findings of this study indicate that Arabic is a verb-framed language (Talmy, 2007). It has a variety of path verbs such as yadheh "fall," yamer "pass," and yenzel "descend." Furthermore, the stative verb is used frequently in Arabic by all the Arabic speakers to describe a static location (Feiz, 2007). The total number of uses of the stative verb in Arabic is 71 tokens. In addition, the verb yati "come" is used in Arabic to introduce newcomers, as it is in English (Feiz, 2007). However, the use of the manner verbs in Arabic, such as etkhardhaf "tumbles," is rare. English is considered a typical satellite-framed language. It has a large number of manner verbs (Slobin, 2003). Some deictic verbs are used with path satellites (e.g., comes along). Manner verbs are also used with path satellites (e.g., climb down and walk back). Multiple path satellites also appear in English (e.g., came down off and climbed back up in).
\end{abstract}

\section{Focus of the Study}

The focus of this paper is the comparative analysis of English and Arabic expressions of motion events using narratives of Chafe's (1980) Pear Story that were elicited from native speakers of Arabic and English. The native-speaker English narratives were elicited by Feiz (2007). A discourse analytic approach is used to examine how speakers of Arabic and English indicate motion through path, manner, and ground. My work is inspired by Feiz (2007), who conducted a similar comparative and constructive study using American English and Persian and based on Chafe's (1980) Pear Film.

The "motion event" is the analytic unit in this study, based on Talmy's (1991, 2000) framework, which covers Figure, Path of motion, and Ground. It can also contain the Cause and Manner. Talmy $(1985,2000)$ classifies the world's languages into satellite and verb-framed languages. Japanese, French, and Arabic are considered verb-framed languages because they express the path in their verbs such as "exit the house skipping." In contrast, English, Chinese and Russian are felt to be 
satellite-framed languages as a result of indicating path through particles, e.g. "skip out of the house" (Talmy, 1991; 2000)

Motion is the basis of the motion event. Talmy's (1985) example of a bottle floating out of a cave in Spanish (a) and English (b) and how these languages encode path and manner are shown below.

(a) La botella salió flotando.

"The bottle exited floating."

(b) The bottle floated out. (p. 487)

In Spanish, the verb, salir "exit" indicates the path, and the manner is presented by using the gerund flotando "floating." In English, the satellite "out" encodes the path and the verb "float" expresses the manner. Spanish is considered a verb-framed language, whereas English represents a satellite-framed language. As a Semitic language, Arabic is considered a verb-framed language (Talmy, 2007). The purpose of this study is to understand the linguistic typology of the Arabic language based on Talmy's $(1991,2000)$ framework.

\section{Language and Conceptualization}

\section{Introduction}

The fact that the world's languages conceptualize space and time in different ways is related to the notion of linguistic relativity (Whorf, 1956; Bloom, 1981; Brown \& Lenneberg, 1954; Levinson, 1994, 1996a, 1996b; Lucy, 1993, 1996; Slobin, 1996a, 1996b, 1998). Linguistic relativity is concerned with the effects of specific language on nonlinguistic cognition. Linguists and psychologists have related grammar to the world, culture, or speakers of the language (Slobin, 2003). Linguistic relativity researchers "should assess the cognitive performance of individual speakers aside from explicit verbal contexts and try to establish that any cognitive patterns that are detected also characterize everyday behavior outside of the assessment situation" (Lucy, 1996, p. 48). In this view, "cognition" is conceptualized as procedures that are carried out whether people are engaged in verbal behavior or not (Slobin, 2003). Another approach to conceptualizing cognition is based on language use and culture. Gumperz and Levinson (1996) emphasize the significance of "theories of use in context," such as semantic and pragmatic theories.

Cognitive linguistics deals with the relationship between language, the mind, and sociophysical knowledge (Evans \& Green, 2005). Cognitive linguists research the relationship between language and cognition (Lakoff, 1990). The cognitive grammar model maintains that language is neither self-contained nor describable without necessary relevance to cognitive processing (Langacker, 1986).

In this section, I will present Talmy's framework of motion events and express their components, which are path, ground, manner, and cause. After that, I will present Slobin's investigations, which are based on some linguistics studies on 
motion that shed light on the "thinking for speaking" idea, which explains how language conceptualization is influenced by language patterns.

\section{Talmy's framework of motion events}

Languages vary in expressing motion, as Talmy (2000) describes events of translocation, in which "an object's basic location shifts from one point to another in space" (p. 35). Talmy (1985) defines the motion event as "a situation containing motion and continuation of stationary location alike" (p. 60): first, we have the figure that is the object or being to be located or traced in space and expressed in the subject NP of a spatial expression; second, there is the activating process which can be in fixed or transited setting and mostly refers to the verb. Because of the changeable nature of the setting, Berthele (2004) prefers to use the term "spatial localization event" rather than "motion event". Third, the path or the association function, such as the preposition, relates the figure to its spatial environment. Finally, the ground is the endpoint of the moving entity. It might constitute the manner of the action, which can range from a general manner, e.g., walk, run, or fly, to a specific manner, such as limp, sprint, or swoop (Talmy, 2000: 25). An example of a motion event is presented in the sentence below (Slobin, 2005):

$\begin{array}{llll}\text { John } & \text { ran } & \text { into } & \text { the room. } \\ \text { FIGURE } & \text { MOTION+MANNER } & \text { PATH } & \text { GOAL } \\ \text { Figure } & \text { activating process } & \text { association function } & \text { ground }\end{array}$

Languages are classified based on lexicalization systems for motion events which focus on path. In verb-framed languages, the path is indicated in the main verb (e.g., enter, exit, ascend, and descend). Romance, Semitic, Turkic, Basque, and Japanese are considered verb-framed languages. In satellite-framed languages, path is encoded by the verb particles or affixes, known as "satellites," that are associated with the main verb, such as in, out, up and down. Germanic, Slavic, and Finno-Ugric are considered satellite-framed languages (Talmy, 1985, 1991, 2000).

Gentner (1981, 1982; Gentner \& Boroditsky, 2001; Gentner \& GoldinMeadow, 2003a, 2003b) recommend analyzing verbs and prepositions, which may show spatial relations more clearly than nouns do. Therefore, the analysis in this study mostly focuses on verbs. This section presents an analysis of the expressions of space that encode path, ground, and manner of motion in the discourse narratives of Arabic and English speakers based on the Pear film. The purpose of the section is to elucidate the status of Arabic with respect to Talmy's typology of languages as $S$ or V-framed.

The relationship between linguistics and the conceptualization of space has been studied by linguists (e.g., Haviland \& Levinson, 1994; Jackendoff, 1983; Pütz \& Dirven, 1997; Senft, 1997; Svorou, 1994; Talmy, 1983). In the field of spatial cognition, Landau and Jackendoff (1993), Hayward and Tarr (1995), and others have proposed that visual representations of space may constrain spatial language. Some expressions used to describe spatial relations (e.g., over, above, on, within) indicate shape (Landau \& Jackendoff, 1993). 


\section{Motion Events and Discourse Analysis}

Slobin (1987) and Berman and Slobin (1994) have applied Talmy's typological framework to different written and oral elicited narratives of various languages, which emphasizes the effect of linguistic typology on the motion events (Slobin 1987, Berman and Slobin 1994, Slobin 1996a, b, 1997, 2000, among others).

\section{Path and Ground}

As noted, Talmy (2000) divided the world languages into two categories based on the path of motion: V-languages and S-languages. Turkish is a typical V-language that encodes the path in its main verb; however, English, considered a typical Slanguage, encodes the path using a satellite connected to the verb (e.g., come down, come back).

Slobin (various) and Berman and Slobin (1994) noticed that speakers of various languages tend to use the morphosyntax of their language in recounting the narratives, and rarely use structures different from their language norm (Slobin, 1987: 439). S-languages might use different path satellites with a path verb in a single clause; therefore, they conflate more than one ground component with a single verb. However, V-languages use a different verb to express each segment (Slobin, 1997, 2004). V-languages use fewer path segments, fewer ground components, and a large number of bare verbs (Slobin, 1996a: 200).

Path is the most important element in Talmy's (2000) framework. This is the trajectory or the figure location with respect to the ground. The path has three elements: the Vector, the Conformation, and the Deictic. The Vector indicates the direction of motion according to the ground (source, endpoint, or midpoint); therefore, it refers to the arrival, traversal, or departure of the figure with respect to the ground (p. 53). Similarly, Johnson (1987) expresses the idea of the Source-PathGoal image schema that structures a finite path. It has three elements: source (starting point), path (the trajectory from the starting point to the endpoint), and goal (endpoint). The confirmation expresses the geometric characteristics of the ground. For instance, if the ground is an enclosure, the path satellite "in" or the path verb "enter" will be used; however, the path verb "reach" will be used to encode the flat surface ground. The deictic element of the path comprises two components of directionality. First, the deictic verb "come" is used to encode movement toward the speaker. Second, the deictic verb "go" is used to encode movement in a direction other than toward the speaker.

\section{Manner and Cause}

Manner and cause are considered co-events of the motion event in Talmy's framework. Manner verbs in V-languages tend to be "telic" (Aske, 1989; Slobin, 2004). Therefore, V-languages use the equivalent of "the owl exited the hole flying" instead of using "the owl flew out of the hole," because its verbal construction cannot encode both manner and boundary-crossing at the same time (Slobin, 2000, p. 112). 
S-languages use satellites to indicate the path, so the manner verb fills the slot of the main verb (e.g., walk, run, fly ... in, out, into). This eases expression of the manner verbs (Slobin, 2000, 2004). S-languages have a large variety of manner verbs that are encoded habitually by their speakers (Slobin 2000, 2004).

In V-languages, the path is encoded in the main verb, so the manner verb does not have a slot in the main verb and is not easily codable. In this case, Vlanguage speakers tend to add some structures to express manner; e.g., exit by running or enter in haste (Slobin, 2004).

Cause is the other co-event of the motion event in Talmy's framework. In the example below, the Figure is the pencil, and the table is the ground. The Path is described by the preposition off. The verb blew indicates the Cause that creates the motion itself (Talmy, 2000, p. 26)

The pencil blew off the table.

However, in Arabic, the prepositional phrase could be used to express the cause of the motion, as in the following example:

(1) Describing the bike boy falling down - speaker \#17

fadhahat qubaatah men elhawaa

"His hat blew off"

(Literally, "His hat fell from the air")

Wa ho ma shaf elhasah elli jedamah ala el sharea

He did not see the rock that was in front of him on the road

Wa etkhardaf fiha

And tumbled over it

The object is his hat. Path is encoded using the path verb dhah "fell," inferring the meaning "falling down," which encodes Direction. The prepositional phrase men el hawaa "from the air" indicates Cause. The source and the ground are not mentioned because the focus here is on the cause of the motion.

\section{Data and Methodology}

\section{Data}

In this section, I will present the details concerning the data elicitation and collection, the methodology used for analysis, and the participants. The data for this study consist of Arabic and English narratives elicited from native speakers of Arabic. Moreover, I used the analysis of the data that was elicited by Feiz (2007), which contains native English speakers. These narratives are based on Chafe's Pear Film.

The data consist of 45 elicited oral narratives. The narratives are all based on Chafe's (1990) Pear Film, which is a 6-minute film with many characters, but no dialogue. Fifteen of these are in Arabic, fifteen in English by the Arabic speakers and fifteen in English by English speakers, as shown in Table 1. 


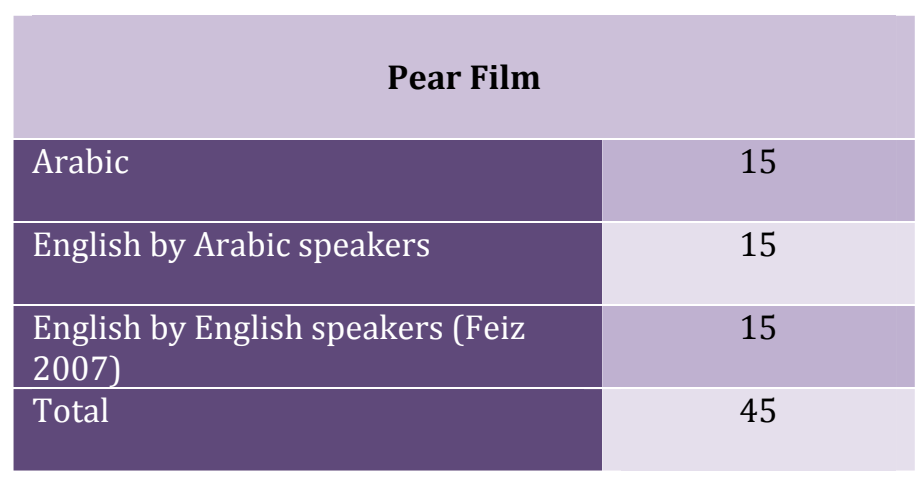

Table 1. Types of narratives and totals

In eliciting the data, I used a short film (Chafe's (1980) Pear Film) that had no dialogue, to give the participants the opportunity to tell the story using their own words, according to their interpretation and understanding of the story events. The emphasis of the analysis is on the variation between Arabic and English. This data elicitation method has been used by other linguists such as Bartlett (1932), Chafe et al. (1980), and Berman \& Slobin (1994). Their studies focus on memory and retelling the stories.

Pear Film was produced in the late 1970s by Wallace Chafe in collaboration with some linguists who were at UC-Berkley. It is a six-minute film with no dialogue, and was created to examine "cognitive, cultural, and linguistic aspects of narrative production" (Chafe, 1980).

The following is a brief summary of Pear:

The story opens with a man picking pears in a pear orchard. He is up in a tree and then comes down his ladder to fill one of his baskets with the pears that he had picked and placed in his apron. After he unloads his apron, he goes back into the tree to pick more. Meanwhile, a boy comes by on his bicycle and steals an entire basketful of pears. As he rides off, with the basket of pears on the front of his bike, he sees a girl riding a bike toward him. He is distracted for a moment and his hat blows off. Then, as he continues to ride, there is a rock in the road that he doesn't see. The front tire of the bike hits the rock and the bike falls down, as does the boy and his entire basket of pears. Three other boys witness this and they come over to the boy to help him pick up the pears and put them back into the basket. In thanks for the three boys' help, the first boy gives them each a pear and he rides away on his bike. The three boys then pass the man who was picking the fruit, and as they pass, they are each eating a pear that was given to them by the boy. The film ends as the boys pass by the man who has a very quizzical look on his face. (Strauss, cited in Feiz, 2007)

The Pear Film narrative data were collected during two weeks in a study group room in the library of a large northeastern public university. The participants watched the film alone, and then recalled it in detail while the researcher audio- and videotaped them. 


\section{Participants}

I collected thirty narratives, fifteen in Arabic from native speakers of Arabic and fifteen in English, from native speakers of Arabic who studied English as a foreign language. The fifteen native-English-speaker narratives were collected by Feiz (2007).

The selection of Arabic speakers was based on the following: 1) all are adult native speakers of Arabic; 2) all have resided in the US for a period of no longer than three years; and 3) all the Arabic speakers use Arabic in their daily life except in their university interactions. Most of the Arabic speakers were undergraduate students. Only one of them was a graduate student. Participants were divided nearly equally between genders: nine female and eleven male. The Arabic speakers were from four different Gulf countries: twelve from the United Arab Emirates, five from Saudi Arabia, two from Oman, and one from Qatar.

\section{Data Analysis: Arabic as Verb Language and English as Satellite Language}

In this section, I will present an overview of Talmy's typology, and provide some examples from Pear Film of Arabic and English L2 data elicitation as an indication of their linguistic typology. Finally, I will provide an inventory of motion verbs in Arabic, English by native speakers (L1), and English by Arabic speakers (L2).

\section{Talmy's typology}

Motion event contains an entity (Figure) that moves through a Path in relation to another object that Talmy (1985) called Ground (p. 85). A motion event might also include an external co-event, which could be Manner and/or Cause. Based on the various lexical structures which languages use to form these elements into linguistics patterns, satellite-framed languages offer their speakers some locative particles to indicate the Path; these particles are called "satellites." Verb-framed languages, on the other hand, have plenty of verbs that are used to encode the change of location; that is, the Path is encoded in the verb.

As noted, English is considered a satellite-framed language. It has a large number of manner verbs such as roll, run, tumble, and scrawl, which can be combined with adverbs, particles or prepositional phrases that express Path information. Nevertheless, path verbs are limited in English. Greek is considered a typical verb-framed language, having path verbs such as beno "enter", and pao "go." These verbs are combined with prepositional phrases or adverbials, such as sto spiti "into the house," to indicate the path. Manner verbs, such as sernome "crawl," are limited in Greek (Aske, 1989; Talmy, 1985; 2000).

\section{Satellite-Framed and Verb-Framed Languages}

English, a typical S-framed language (Talmy, 2007), combines the fact of motion with the manner or cause; therefore, its lexicon is rich of manner-of-motion verbs, e.g., stride, stroll, skip, etc. An S-framed language indicates the Path through verb 
particles or affixes attached to the verb as a satellite (Talmy, 2000), which is "the grammatical category of any constituent other than a noun phrase or prepositional phrase-complement that is in a sister relation to the verb root" (p. 102).

In V-languages, the Path is lexicalized within the verb of motion but the manner might be mentioned using adverbs; therefore, this type of language has many different path verbs, e.g., exit, ascend, etc. (Talmy, 2000). Spanish and Semitic languages such as Arabic represents V-framed language (Talmy, 2007).

\section{Examples from Pear Film: Arabic and English L2 Data Elicitation}

In this section, I provide examples from my data that illustrate Arabic as a verbframed language. I also present examples from Feiz (2007) that illustrate English as a satellite-framed language.

\section{Arabic as a Verb-Framed Language}

\section{Stative Verb}

In describing the location of an object, three components are relevant: the object of interest, or Figure; a reference object, or Ground; and a locative component which points out the spatial relationship between the Figure and the Ground. Figure and Ground are described using noun phrases, and locative components are indicated through morphemes such as prepositions, postpositions, affixes, or predicates such as verbs (Kemmerer \& Tranel, 2000). For instance, this is expressed in the phrase "the bird on the tree." The NP the bird describes the Figure; the NP the tree describes the Ground; and the preposition on indicates the spatial relationship between the Figure and the Ground.

The stative verb is used frequently in Arabic to describe a static location (Feiz, 2007). The total number of uses of the stative verb in Arabic is 71 tokens, as shown in the table below:

$\begin{array}{lllllllllllllllll}\text { Speakers } & \mathbf{1} & \mathbf{2} & \mathbf{3} & \mathbf{4} & \mathbf{5} & \mathbf{6} & \mathbf{7} & \mathbf{8} & \mathbf{9} & \mathbf{1 0} & \mathbf{1 1} & \mathbf{1 2} & \mathbf{1 3} & \mathbf{1 4} & \mathbf{1 5} & \text { Total } \\ \begin{array}{l}\text { kan "verb } \\ \text { to be" }\end{array} & 4 & 3 & 3 & 1 & 5 & 7 & 1 & 7 & 1 & 10 & 6 & 6 & 7 & 9 & 2 & \mathbf{7 1}\end{array}$

Table 2: Frequent use of stative verbs in Arabic

I explain below two excerpts that indicate the use of the stative verb in Arabic. In excerpt 2, the adverb foq "top" is used with the verb kan "to be" to describe the first scene of the pear story and express the location of the pear picker. In example 3 , the adverb ala "top" is used to describe the location of the bike boy toward the bicycle.

(2) (Speaker 13) - static location

Bada enah wahed kan foq elshaiarah

The movie started that someone was in the top of the tree 
Yenazel elthmar ehh elruman ala ma ateqed ehh la alkumathrah

He brings the fruit down ehh pomegranate as I think ehh no pears

(3) (Speaker 2) - static location

Kan ala elsakel wa harak

He was on the top of the bicycle and moved

wa nus adhareeq daam elwalad elli ala esikel

And in the half way, the boy on the bicycle hits

Daam ahh hasah ala elardh

hits rock that was on the ground

\section{Path Verbs}

In V-languages, the path is lexicalized within the verb of motion but the manner might be mentioned using adverbs; therefore, this type of language has many different path verbs, e.g., exit, ascend, etc. (Talmy, 2000). The Spanish language and Semitic languages such as Arabic represent V-framed languages (Talmy, 2007).

Some path verbs used in Arabic by native speakers are presented in the following paragraphs. These demonstrate Arabic to be a Verb-framed language.

\section{Yadheh "Fall"}

In excerpt 4, the path verb yadheh "fall" infers the semantics of "falling down," which encodes the direction. The preposition men "from" is used to point to the source "the pear picker" while he was picking the pears. In excerpt 5 it is used to indicate the source "the bicycle". The endpoint of the trajectories in those two scenes, which is the ground, could be inferred. Yadheh "fall" is the second most frequent path verb used intransitively in the Pear narratives by the Arabic speakers.

(4) Description of the pear picker's actions - speaker \#4

Wahed ayal kan yeyemea jawaf

A man was collecting pears

Wa ehh wa kan yeame

And ehh and while he was collecting

Dhahat menah jawafah wahedah one pear fell from him

(5) Description of the bike boy falling - speaker \#10

Famar end eeh dhefel thani

Then passed by ehh another child

Famen elhawa dhar elqubaah haqhetah fi elardh

Then his hat blew off from the air and fell on the ground 
Kan yedhalea fi elqubaah

He was looking for the hat

Wa dhah men elsikel

And fell from the bicycle

Yamer "Pass"

The path verb yammer "pass" is a frequent verb in Arabic; there are 26 tokens of it in the pear stories. It is used intransitively and encodes the trajectory of the motion. Using this verb indicates the ground dhefel thani "another child." The semantics of the verb pass consist of "move + by" (Feiz, 2007).

(6) Description of the bike boy passing by the other boy - speaker \#10

Wa masha baadha eldhefel elsareq

And the thief boy walked after that

Kan yerkab eldarajah haqetah

He was riding his bicycle

Famar end eeh dhefel thani

Then he passed by ehh another child

Famen elhawa dhar elqubaah haqhetah fi elardh

Then his hat blew off from the air on the ground

Yenzel "Descend"

The path verb descend encodes the path because it combines the verb move and the adverb down. The ground tree is inferred from the scene without explicitly mentioning it.

(7) Description of the pear picker's actions - speaker\# 13

Wa hatha baadah yales yejamea kumathrah elli fuq

And he was picking up the pears

Yales yeame yeame

He was collecting the pears

baad ma enhafat elsalah menah

and the basket was stolen from him

Fal eyal mareen

Then the boys passed

Wa howa nazal tahat

And he descended down

We ela entabah enah fi salah mekhtafiah kamel

Then he noticed that a whole basket disappeared 
Four speakers use the path verb yenzel "descend," which combines the fact of motion and the trajectory down. They specify the source tree using the preposition men "from." Example (8) illustrates this:

(8) Description of the pear picker's actions with Nazal men - speaker \#6

Wa bad entihaeh men qadhf alfakeha

And after he finished from picking the fruit

Nazal men alshajarah

He descended from the tree

Yaaber "Cross"

The path verb abar "cross" is used to describe the appearance on the scene for the first time of the man with the donkey (Feiz, 2007). This path verb is used intransitively, which encodes the path. The ground is the pear picker, which is inferred from the scene. The ground is used only by speaker \#13, but it is used five times, as the example below shows:

(9) Description of the man with the donkey - speaker \#13

Elqhsah kanat tetkalam an muzarea

The story was about a farmer

Kan yeqhdef el kumathrah men elshajarah

He was picking the pears from the tree

Mar

He passed

Kan yeqhdhef

He was picking the pears

Wa jamaa endah fi salat

And he was collecting them in baskets

Abar janbah rajal we endah hemar

A man crosses by him with a donkey

Yered "Return"

The verb yered "return" conflates the deictic verb go and the particle back. The ground, which is the tree, can be inferred from the scene.

(10) Describing the pear picker's actions with yered "return" - speaker \#2

Kan yehawel yeabi thalath salat kumathrah

He was trying to fill up three pear baskets

Ma aba ela ethnin

But he filled only two baskets 


\section{Frad foq asab Yeabi ethaltha}

The he returned up to fill the third

\section{English as a Satellite-Framed Language}

Satellite-framed languages encode the trajectory through verb particles or affixes attached to the verb as a satellite, which is "the grammatical category of any constituent other than a noun phrase or prepositional phrase-complement that is in a sister relation to the verb root" (Talmy, 2000, p. 102).

In English, verb particles and prepositions appear after the verbs, so it is important to know how to distinguish between path satellites and prepositions. Prepositions require a complement, but satellites can appear intransitively (Talmy, 1985, p. 105). Navarro \& Nicoladis (2005) state that L1 and L2 Spanish speakers obviously prefer conflating the path with intransitive verbs.

In this example, the deictic verb come is used with the adverb along, which constitutes a satellite. The path satellite along is connected to the deictic verb come to describe the appearance of the boy on the bike. It emphasizes the visible appearance of the object on the scene (Feiz, 2007). Examples $11-15$ are from Feiz (2007).

(11) Introducing the boy on the bike with come - Speaker \#3

A kid with a bi^ke, (.) comes alo:^ng, (...). $0^{\wedge}$ kay so the $\mathrm{ki}^{\wedge} \mathrm{d}^{\prime} \mathrm{s}$ on a new $\mathrm{bi}^{\wedge} \mathrm{ke}, \mathrm{a}^{\wedge}$ lso wearing a red scarf and $\mathrm{a} h \mathrm{a}^{\wedge} \mathrm{t}$.

Manner expresses how the object moves. In English, verbs mainly indicate manner information (Billman, Swilley, \& Krych 2000). English speakers typically use verbs that express information about manner, such as skip and walk, rather than path (e.g., approach, ascend), while Greek speakers use path verbs more, evidence that their language is a typical V-framed language (Papafragou, Hulbert, \& Trueswell, 2008). "Manner is the way in which motion is accomplished. It includes different dimensions such as motor pattern (e.g., hop, jump, skip), rate motion (e.g., walk, run, sprint), force dynamics (e.g., step, tread, tramp), or attitude (e.g., amble, saunter, stroll), and encoding instrument (e.g., sled, ski, skateboard)." (Slobin, 2006).

Most of the examples below illustrate the way English indicates the manner and path in a single clause. In excerpt 12, the intransitive expression ride away encodes the path of motion separately from the verb through the satellite. The path satellite away is connected to the manner verb ride. The co-event of manner is presented through the verb ride:

(12) Intransitive motion in English - [verb: ride away] en he (the boy) $\mathbf{r i}^{\wedge} \mathbf{d e s}$ awa:^${ }^{\wedge} \mathbf{y}$, en he's not even looking back to see if the gu:^y $\mathrm{i}^{\wedge} \mathrm{s}$ looking at him,= 
In example 13, the adverb down is used as a path satellite that connects to the manner verb climb to encode the trajectory of the motion. Down encodes the direction of the pear picker:

(13) Path satellite in English and then he (the pear picker) climbs down the $1 a^{\wedge} \mathrm{dde}^{\wedge} \mathrm{r} .=$ it's up next to the tree:^,

In excerpt 14, the particle back used as a path satellite, which connects to the manner verb walk:

(14) Path satellite in English

A: nd e: so they walk- three boys wa^ $\mathbf{a}^{\wedge} \mathbf{k}$ back towards where the $0^{\wedge} \mathrm{ld}$ ma:^n -

the $\mathrm{mi}^{\wedge}$ ddle aged $\mathrm{ma}^{\wedge} \mathrm{n}$ is $\mathrm{pi}^{\wedge}$ cking pea:^rs,

Moreover, more than one path satellite can be used in English, as illustrated in excerpt 15. Two path satellites down off are used with the deictic verb come, and three path satellites back up into are used with the manner verb climb.

(15) Multiple path satellites in English -Speaker \#10

he:^ came do^^ ${ }^{\wedge}$ off of the ladde:^r, (.)

he was wearing a red $\operatorname{sca}^{\wedge} \mathrm{rf},($.

he used the scarf to clea^n off the pea:^rs, (0.4)

a:nd he climbed back $\mathbf{u}^{\wedge} \mathbf{p}$ into the tree:^,

Inventory of Motion Verbs in Arabic, English by Native Speakers (L1) and English by Arabic speakers (L2)

In this section, I will present a general analysis of the verb inventories of motion verbs in Arabic, English by native speakers (L1) and English by Arabic speakers (L2), as outlined in table 3 below.

\begin{tabular}{|ll|}
\hline \multicolumn{2}{|c|}{ Motion verbs } \\
\hline English & 85 \\
\hline Arabic & 26 \\
\hline English by Arabic speakers & 21 \\
\hline
\end{tabular}

Table 3: Breakdown of motion verbs by language

It can be seen that native English speakers use motion verbs more than three times as often as motion verbs used by Arabic speakers in Arabic or English.

\section{Arabic Pear Stories}

Fifteen narratives of the Pear Film story were elicited in Arabic from Arabic speakers. Twenty six different types of Arabic motion verbs were used, divided between fifteen intransitive verbs and eleven transitive verbs, as follows: 


\section{Intransitive}

Path verbs are:

yammer "pass"

yenzel "descend"

Raja "turn around"

rad "return"

abar "cross"

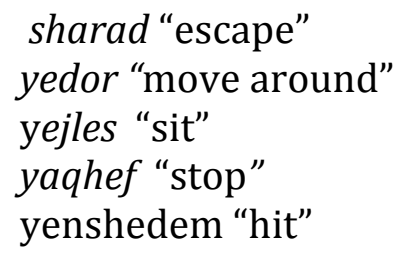

Deictic verbs that indicate directionality are:

yarooh "go"

yati "come"

Manner verbs are:

Etkhardhaf "tumble" yhather "fly off" rakadh "run"

The one verb encoding directionality is:

yeqheh "fall"

Transitive

Path verbs are:

yesaad "help"

yekhamel "complete"

yeqhadhee "pick"

yehadhi "put"

$$
\begin{aligned}
& \text { yejemee "collect" } \\
& \text { yasreq "steal" } \\
& \text { yekhali "leave" } \\
& \text { yaqhdhef"pickup" }
\end{aligned}
$$

Deictic verbs that indicate directionality are:

yakheth "take" yaadhi "give"

The lone manner verb is:

yerkab "ride"

The significant characteristic of this inventory is the huge number of the two intransitive verbs yarooh "go" (33) and yeqheh "fall" (32). The most frequent intransitive verbs used by Arabic speakers are yarooh "go," yeqheh "fall," yammer "pass," yenzel "descend," raja "turn around," and rad "return." Moreover, we notice a salient decrease from yeqheh "fall," with 32 tokens, to yammer "pass," with 26 tokens; and from yammer "pass" to yenzel "descend," with 14 tokens. However, the sharp decline in the transitive verbs occurs only between the first two frequent verbs that decrease from yakheth "take," with 28 tokens, to yesaad "help," with 12 tokens. 


\section{English Pear Stories by Arabic Speakers}

I collected a total of fifteen English Pear narratives by Arabic speakers, and identified a total of 21 motion verbs: ten intransitive and eleven transitive. The most repeated verbs in each category of verb are as follows:

Intransitive: pass, ride, return, move, sit, and stop. Go and come are deictic verbs. Walk and run are manner verbs.

Transitive: put, pick, help, steal, fill, hit, collect, leave, clean. Take and give are deictic verbs.

The important characteristic of the inventory is the large number of tokens of the two intransitive verbs pass (39) and go (32). The most frequent intransitive English verbs used by Arabic speakers are come, ride, and walk. There is a decrease in the total number of tokens from the second most frequent verb, go (32) to the third most frequent verb, come (19), and a gradual decrease from walk (11) to return (2).

\section{English Pear Stories by Native Speakers}

Feiz (2007) elicited 15 English narratives of the Pear Film story produced by native speakers. The total number of English motion verbs is 85, with 40 intransitive verbs and 45 transitive verbs, as follows:

Intransitive: walk, come, ride, go, and fall. Walk and ride indicate manner. Come, go, and fall encode directionality.

Transitive: put, pick, take, pick up, and give. Pick encodes some degree of manner. Pick up, take, and give encode directionality.

The important feature of the inventory is the large number of the same intransitive verbs walk (71), come (46), ride (45), go (39), and fall (27). The most frequent intransitive English verbs used by native speakers are walk, come, and ride. We can also observe a sharp decrease from walk, with 71 tokens, to come, with 46 tokens; and from go, with 39 tokens, to fall, with 27 tokens. Some intransitive verbs are used only once by the participants: kneel down, leave, jump off, hold on, splat, move (around), appear, bump into, spill, bounce, lean, blow off, wobble. Limp (off), smack (into), wobble, etc. are finer-grained manner verbs. The same pattern of decrease is noticed in the transitive type (Feiz, 2007).

\section{Conclusion}

This paper is a comparative analysis of motion events surrounding space and manner in Arabic and English narratives elicited from native speakers after watching Pear Film. The analysis is based on Talmy's framework of motion events and his linguistic typology (satellite-framed languages and verb-framed languages). The emphasis of the analysis is on the main elements of motion, which are Figure, Path, Manner, and Ground.

I start with a brief discussion of Talmy's typology of satellite-framed and verb-framed languages. I then move on to providing some examples from Arabic 
and English data elicitation. The instances presented from Arabic clearly show evidence of its being a verb-framed language. Likewise, in the following section the examples from English narratives by native speakers taken from Feiz's (2007) research indicate that English is a typical satellite-framed language. In the following section, I present an inventory of motion verbs in Arabic, in English by native speakers (L1), and in English by Arabic speakers (L2).

My conclusion based on the findings of this study is that Arabic is a V-framed language as defined by Talmy (2007). At the same time, some examples from the Arabic narratives express co-events of the motion event, which are manner and cause of movement. These are rarely used in Arabic. However, their linguistic patterns are different from Talmy's expected structures in his framework; for instance, using verbs that encode path and manner, such as etkhardhaf "tumbles," and using the prefix $t$ to indicate manner, which does not fit into Talmy's classification of satellite-framed structures. Furthermore, in Arabic, prepositional phrases are used to encode cause.

Some implications will be discussed regarding Talmy's typology in the following paragraphs. Findings from some other studies, such as some done on Chinese, would seem to recommend revisiting Talmy's linguistics typology. The analysis of resultative verb compounds in Chinese poses a problem in Talmy's conceptual approach and his linguistic typology. Chinese speakers focus more on the result; however, English speakers pay attention more to the process of an event (Tai 2003).

\section{Implications for Teaching English to Arabic Speakers}

Because manner verbs are used rarely in Arabic, as noted earlier, some teaching strategies and materials should be used to teach Arabic learners of English manner verbs. One strategy for teaching English to native speakers of Arabic could be using some films that include a large variety of motion verbs, especially manner verbs, such as Pear Film. Some online stories could be used to teach children the manner verbs, such as those found at http://www.storylineonline.net/. Role-playing could be a strategy to learn some manner verbs in the classrooms, by acting out these verbs. Pictures could also be used to illustrate them.

In addition, Arabic learners need to learn the different semantics of some path satellites that are connected to manner or deictic verbs. For instance, some pictured short stories could be beneficial for children, such as those found at http://www.magickeys.com/books/ollie/index.html, to visualize and understand the meaning of manner verbs and path satellites.

\section{References}

Aske, J. (1989). Path predicates in English and Spanish: A closer look. Proceedings of the Annual Meeting of the Berkeley Linguistics Society, 15, 1-14.

Bartlett, F. C. (1932). Remembering: A Study in Experimental and Social Psychology. Cambridge, Eng.: Cambridge University Press. 
Berman, R. A., and Slobin, D. (1994). Relating events in narrative: A crosslinguistic developmental study. Hillsdale, NJ: Lawrence Erlbaum.

Berthele, R. )2004). The typology of motion and posture verbs: A variationist account. In B. Kortmann (Ed.), Dialectology meets typology (pp. 93-126). Berlin: Mouton de Gruyter.

Billman, D., Swilley, A., \& Krych, M. (2000). Path and manner priming: Verb production and event recognition. Proceedings of the 22nd Annual Conference of the Cognitive Science Society. Hillsdale, NJ: Lawrence Erlbaum.

Bloom, A. H. (1981). The linguistic shaping of thought: A study in the impact of language on thinking in China and the West. Hillsdale, NJ: Lawrence Erlbaum.

Brown, R., \& Lenneberg, E. (1954). A study in language and cognition. Journal of Abnormal and Social Psychology, 49, 454-462.

Chafe, W. (1980). The Pear Stories: Cognitive, Cultural, and Linguistic Aspects of Narrative Production. Norwood, NJ: Ablex.

Evans, V., \& Green, M. (2005). Cognitive linguistics: An introduction. Edinburgh: Edinburgh University Press.

Feiz, P. (2007). The expression and conceptualization of motion through space and manner of motion in Persian and English: A comparative analysis. Unpublished doctoral dissertation, Pennsylvania State University.

Gentner, D. (1981). Some interesting differences between nouns and verbs. Cognition and Brain Theory, 4(2), 161-178.

Gentner, D. (1982). Why nouns are learned before verbs: Linguistic relativity versus natural partitioning. In S. Kuczaj (Ed.), Language development. Vol. 2. Language, thought and culture (pp. 301-334). Hillsdale, NJ: Lawrence Erlbaum.

Gentner, D., \& Boroditsky, L. (2001). Individuation, relativity and early word learning. In M. Bowerman \& S. Levinson (Eds.), Language acquisition and conceptual development (pp. 215-256). Cambridge, Eng.: Cambridge University Press.

Gentner, D., \& Goldin-Meadow, S. (Eds.). (2003a). Language in mind: Advances in the study of language and thought. Cambridge, MA: MIT Press.

Gentner, D., \& Goldin-Meadow, S. (2003b). Whither Whorf. In D. Gentner \& S. GoldinMeadow (Eds.), Language in mind: Advances in the study of language and cognition (pp. 3-14). Cambridge, MA: MIT Press.

Gumperz, J. J., \& Levinson, S. C. (Eds.) (1996). Rethinking linguistic relativity. Cambridge, Eng.: Cambridge University Press.

Haviland, J. B., \& Levinson, S. C. (Eds.) (1994). Spatial conceptualization in Mayan languages. Special issue of Linguistics, 32. 
Hayward, G., \& Tarr, M. (1995). Spatial language and spatial representation. Cognition, 55, 39-84.

Jackendoff, R. (1983). Semantics and cognition. Cambridge, MA: MIT Press.

Johnson, M. (1987). The body in the mind: The bodily basis of meaning, reason, and imagination. Chicago: Chicago University Press.

Kemmerer, D., \& Tranel, D. (2000). A double dissociation between linguistic and perceptual representations of spatial relationships. Cognitive Neuropsychology, 17, 393-414.

Lakoff, G. (1990). 'The invariance hypothesis: Is abstract reason based on imageschemas?' Cognitive Linguistics, 1, 1, 39-74.

Landau, B., \& Jackendoff, R. (1993). "What" and "where" in spatial language and spatial cognition. Behavioral and Brain Sciences, 16, 217-238.

Langacker, R. W. (1986). An introduction to cognitive grammar. Cognitive Science, 10,1-40.

Levinson, S. (1994). Vision, shape, and linguistic description: Tzeltal body-part terminology and object description. Linguistics, 32, 791-855.

Levinson, S. (1996a). Relativity in spatial conception and description. In J. Gumperz \& S. Levinson (Eds.), Rethinking linguistic relativity. Cambridge, Eng.: Cambridge University Press.

Levinson, S. (1996b). Frames of reference and Molyneux's question: Crosslinguistic evidence. In P. Bloom, M. Peterson, \& M. Garrett (Eds.), Language and space. Cambridge, MA: MIT Press.

Lucy, J. (1993). Grammatical categories and cognition. Cambridge, Eng.: Cambridge University Press.

Lucy, J. (1996). The scope of linguistic relativity: An analysis and review of empirical research. In J. J. Gumperz \& S. C. Levinson (Eds.), Rethinking linguistic relativity (pp. 37-69). Cambridge: Cambridge University Press.

Navarro, S., \& E. Nicoladis, (2005). Describing motion events in adult L2 Spanish narratives. In D. Eddington (Ed.), Selected Proceedings of the 6th Conference on the Acquisition of Spanish and Portuguese as First and Second Language (pp. 102-107). Somerville, MA: Cascadilla Proceedings Project,.

Papafragou, A., Hulbert, J., \& Trueswell, J. (2008). Does language guide event perception? Evidence from eye movements. Cognition, 108, 155-184.

Pütz, M., \& Dirven, R. (Eds.). (1997). The construal of space in language and thought. Berlin: Mouton de Gruyter.

Senft, G. (Ed.) (1997). Referring to space: Studies in Austronesian and Papuan Languages. Oxford: Oxford University Press. 
Slobin, D. (1987). Thinking for speaking. Proceedings of the Berkeley Linguistic Society, 13, 435-445.

Slobin, D. (1996a). Two ways of travel: Verbs of motion in English and Spanish. In M. Shibatani \& S. Thompson (Eds.), Grammatical constructions: Their form and meaning. Oxford: Clarendon Press.

Slobin, D. (1996b). From "thought and language" to "thinking for speaking." In J. J. Gumperz \& S. Levinson (Eds.), Rethinking linguistic relativity (pp. 70-96). Cambridge, Eng.: Cambridge University Press.

Slobin, D. I. (1997). Mind, code, and text. In J. Bybee, J. Haiman, and S. A. Thompson (Eds.), Essays on language function and language type: Dedicated to T. Givon (pp. 107-138). Amsterdam: John Benjamins.

Slobin, D. (1998). Verbalized events: A dynamic approach to linguistic relativity and determinism. Working Papers for the LAUD Symposium. Essen, Ger.: Linguistic Agency University; GH Essen.

Slobin, D. I. (2000). Verbalized events: A dynamic approach to linguistic relativity and determinism. In S. Niemeier \& R. Dirven (Eds.), Evidence for linguistic relativity, 107-138. Berlin: Mouton de Gruyter.

Slobin, D. I. (2003). Language and thought online: Cognitive consequences of linguistic relativity. In D. Gentner \& S. Goldin-Meadow (Eds.), Language in mind: Advances in the study of language and thought (pp. 157-191). Cambridge, MA: MIT Press.

Slobin, D. I. (2004). The many ways to search for a frog. In S. Stromqvist and L. Verhoeven (Eds.), Relating events in narrative: Typological and contextual perspectives. Mahwah, NJ: Lawrence Erlbaum.

Slobin, D. (2005). Linguistic representations of motion events: What is signifier and what is signified? In C. Maeder, O. Fischer, \& W. J. Herlofsky (Eds.), Outisde-in, inside-out: Iconicity in language and literature, Vol. 4. Amsterdam: John Benjamins.

Slobin, D. I. (2006). What makes manner of motion salient? Explorations in linguistic typology, discourse, and cognition. In M. Hickmann and S. Roberts (Eds.), Space in languages: Linguistic systems and cognitive categories. Philadelphia: John Benjamins.

Svorou, S. (1994). The grammar of space. Amsterdam: John Benjamins.

Tai, James H-Y. 2003. Cognitive relativism: Resultative construction in Chinese. Language and Linguistics, 42, 301-316.

Talmy, L. (1983). How language structures space. In H. Pick \& L. Acredolo (Eds.), Spatial orientation: Theory, research and application (pp. 225-282). New York: Plenum. 
Talmy, L. (1985). Lexicalization patterns: Semantic structure in lexical forms. In T. Shopen (Ed.), Language typology and syntactic description (pp. 57-149). New York, NY: Cambridge University Press.

Talmy, L. (1991). Path to realization: A typology of event conflation. Proceedings of the Seventeenth Annual Meeting of the Berkeley Linguistics Society, 17, 480519).

Talmy, L. (2000). Toward a cognitive semantics. Volume 2. Cambridge, MA: MIT Press.

Talmy, L. (2007). How languages represent motion events: Typologies and universals. Invited presentation, Department of Linguistics and Applied Language Studies, Pennsylvania State University. 4/28/07.

Whorf, B. (1956). Language, thought, and reality: Selected writings of Benjamin Lee Whorf. Ed. J. B. Carroll. Cambridge, MA: MIT Press. 